\title{
SETTING THE FARM ANIMAL WELFARE SCENE IN NORTH AMERICA ESTABELECENDO O CENÁRIO DE BEM-ESTAR ANIMAL NA AMÉRICA DO NORTE
}

\author{
ANNA K. JOHNSON ${ }^{1}$
}

\begin{abstract}
The main areas of interest that this paper will address are to, set the scene on what animal welfare is, the schools that one can subscribe and how this could influence the direction that farm animal welfare could go. Second, to provide an overview on some of the critical farm animal welfare events that have occurred over the past 10 years in North America and finally to detail the legislative events; past and future that will affect farm animal welfare. Animal welfare is not a term that arose in science to express a scientific concept; rather it arose in western civilization through society to express ethical concern regarding the treatment of animals. There are three "schools of welfare", the first school is feeling-based, the second is functioning-based and the third is nature-based. Over the past decade there has been an escalation of welfare related events in North America, ranging from agribusiness and marketing through to humane and animal rights groups. These events include under cover investigations that have been conducted on farm and in plants. There have been numerous campaigns against fast food chain restaurants and more recently humane and rights groups have purchased shares into these companies to voice their opinions and to have a vote. In addition there has been a push for assuring on farm animal welfare through a plethora of assessment, certification and third party auditing programs. More recently, successful legislative initiatives have altered the way producers are able to house farm animals in several states and in 2005 there was an update to the 28 hour rule. In conclusion, all individuals involved in keeping animals for food have a huge responsibility in making sure that their animals are housed, raised, transported and processed humanely. In addition agribusinesses will need to show increasing accountability back to their customers and consumers that farm animal welfare is of critical importance.
\end{abstract}

Keywords: Farm Animal, U.S.A., Welfare.

\footnotetext{
1 Assistant Professor Animal Behavior and Welfare. Department of Animal Science, lowa State University, Ames, IA, 50021, USA. johnsona@iastate.edu
} 


\section{RESUMO}

As principais áreas de interesse que esse trabalho apontará são estabelecer um cenário em que a questão de bem-estar se enquadre, as escolas de pensamento que podem ser descritas e como isso podem influenciar a direção que o bem-estar de animais confinados podem tomar. Segundo, prover uma revisão sobre os eventos críticos de animais confinados que ocorreram nos últimos dez anos na América do Norte e, finalmente, detalhar eventos legislativos do passado e futuro, que podem afetar a questão de bem-estar animal. Bem-estar animal não é um termo que apareceu na área científica para expressar um conceito, mas sim apareceu na civilização ocidental, através de expressão da sociedade, para traduzir a preocupação ética com relação ao trato dado aos animais. Há três escolas de pensamento com relação ao bem-estar animal: a primeira é baseada no sentimento, a segunda, na relação funcional e, a terceira, nas respostas da natureza. Nas últimas décadas houve uma escalada de eventos pautados nas questões de bem-estar animal na América do Norte, desde aquelas do agronegócio e mercado, até outras de grupos de direitos humanos e animais. Esses eventos incluem investigações capciosas conduzidas em fazendas e plantas de processamento. Houve inúmeras campanhas contra os restaurantes de "fast food" e, mais recentemente, os grupos de proteção humana e animal adquiriram ações dessas companhias para expressarem suas opiniões, inclusive com direito a voto. Em adição a isso, tem havido pressão para assegurar o bem-estar de animais em produção, através da sua medida adequada, certificação e ainda a certificação por uma terceira parte, proveniente de programa de auditoria. Mais recentemente, iniciativas legislativas tiveram sucesso na alteração da forma com que o produtor está habilitado a alojar animais nas fazendas criatórias, nos vários estados e, em 2005, houve uma atualização da regra das 28 horas. Em conclusão, indivíduos envolvidos na produção de animais para consumo humano têm uma enorme responsabilidade em garantir que esses animais sejam alojados, produzidos, transportados e processados de maneira humanitária. Em adição, o agronegócio necessitará mostrar compulsoriamente a seus clientes e consumidores, que o bem-estar de animais para produção é uma questão importante.

Palavras-chaves: Animal de Produção, E.U.A., Bem-Estar.

\section{Welfare and schools of thought}

Animal welfare is not a term that arose in science to express a scientific concept; rather it arose in western civilization through society to express ethical concern regarding the treatment of animals. There are three "schools of welfare" and depending on which school an individual subscribes to will often influence the philosophical definitions of welfare to which they subscribe. The first school is a feeling-based school. Definitions would often include some reference to the importance of ascertaining what the animal feels in regards to pleasure, suffering, distress and pain. The second school is a functioning-based school where a focus on the animals' fitness and health are of important consideration. The third school is a nature- based school that values the animals' natural behaviors under natural conditions. Often welfare researchers will formulate their own definitions that cross over one or more of the outlined schools of thought (Broom, 1986, Duncan and Petherick, 1991). In turn, due to these variable schools of thought welfare researchers are still unable to agree on one welfare definition. Several definitions of welfare can be found and ascribed to. For example, Warnier and Zayan (1985), Broom, 1986, Mormède (1990) and Barnett et al., (1991) have ascribed to physiological and behavioral indicators. The idea that feelings being important for welfare was gradually developed by Duncan (1981), Duncan and Dawkins (1983) and then 
the suggestion was made that, in fact feelings were the only thing that mattered (Duncan and Petherick, 1991). The importance of an individual's philosophies and definition of welfare will have enormous consequences for the U.S.A. animal commodity groups in regards to the advice, information and direction that maybe given on the policies and procedures on farm animal welfare.

Historically, in the U.K. a controversial book by the author R. Harrison entitled "Animal Machines" was released in 1964, and this book detailed how farm animals were housed, raised, transported and processed for food. The book caused a lot of public concern and the U.K. government formed a committee called the Brambell committee (Brambell Command Paper 2836, 1965), which was composed of several leading veterinarians and animal scientists of the time. After extensive review of the literature the committee created a charge for more research to be conducted in the field of farm animal welfare and in addition created five so called "freedoms" that all farm animals should have. To date many welfare codes, programs, assurance schemes and laws in the U.K. and elsewhere are based around the central premise of the five freedoms. In the U.S.A. during the 1970's activities by certain individuals and groups whose purpose related to increased awareness and sensitivity to animal welfare issues occurred. In 1975 Peter Singer completed the book "Animal Liberation", in 1980, Jim Mason and Peter Singer collaborated on a book entitled "Animal Factories".

\section{What are the farm animal welfare chal- lenges?}

\section{Campaigns}

Animal commodity groups have been and continue to be challenged from individuals and groups outside of the traditional production sector. These challenges come from groups that range in their demands from those that do not agree with raising animals for food production (PETA, 2008) to groups who oppose specific production practices or housing systems (AWI, 2003; HSUS, 2003, 2008a). In the mid 1990's the People for the Ethical Treatment of Animals (PETA) began actively targeting food service companies under a variety of slogans for example "McCruelty", "Murder King" and "'Death in the Box" to highlight a few. McDonalds and Burger King formed their own Animal Welfare Committees to formulate animal welfare guidelines that their suppliers were to subscribe to. In 2000 McDonalds published their welfare guidelines and in 2001 Burger King followed suit. Although they later retracted the letter, in late 2001, Applebee's sent out a detailed letter to their vendors insisting that they only purchase meat from suppliers that:

(1) Begin a process to phase out farms that continuously confine sows,

(2) Immediately euthanize any animals at the slaughterhouse which are overheated or in severe pain,

(3) Continuously improve the minimum living conditions of farm animals and

(4) Not to accept any product from suppliers that mutilates animals for convenience.

More recently, PETA has applauded Kentucky Fried Chicken (KFC) in Canada noting that "KFC Canada gives in to PETA's demands." In the news release PETA reported that for "more than five years, PETA has been pressuring fast-food chain KFC to stop the worst abuses of chickens, like scalding birds to death, slitting their throats while they're still conscious, and drugging and breeding them to grow so large that they cripple beneath their own weight. Now PETA has scored a major victory and is ending its Kentucky Fried Cruelty boycott in Canada. The boycott will continue in other countries where KFC has restaurants, including the United States, until they follow KFC Canada's lead. Following months of closed-door negotiations between PETA and KFC Canada we are thrilled to announce that KFC Canada has agreed to a historic new animal welfare plan that will dramatically improve the lives and deaths of millions of chickens killed for KFC Canada" (PETA, 2008a). According to PETA's report, KFC Canada will take the following actions:

(1) Phase in purchases of $100 \%$ of its chickens from suppliers that use controlledatmosphere killing (CAK),

(2) Add a vegan faux-chicken item to the menu of all 461 Priszm-owned KFC restaurants (more than half of all the KFC's in Canada),

(3) Improve its animal welfare audit criteria to reduce the number of broken bones and 
injuries suffered by birds and

(4) Urge its suppliers to adopt better practices, including improved lighting, lower stocking density and ammonia levels, and a phase out of growth-promoting drugs and breeding practices that painfully cripple chickens.

Additional on going PETA campaigns to note include "WOOF" which is posing the question; "what is the difference between the animal you call dinner and the animal you share your home with?" that provides a comparison between dogs and pigs (PETA, 2008b) and a graphic video entitled "Meet your meat" (PETA, 2008c).

Burger King on March $28^{\text {th }}, 2007$ in an article entitled "Burger King sets precedent in Fast Food Sector" reportedly sent a letter to PETA and Humane Society of the United States (HSUS) outlining its new set of animal welfare policies aimed at reducing its support for some of the worst farm abuses. As a result of this initiative Wayne Pacelle, president and CEO of HSUS was quoted as saying "With its new policy changes, Burger King is signaling to agribusinesses that the most inhumane factory farming practices are on the way out. As a result of this decision, large numbers of farm animals across the nation will be spared much needleless suffering. The more consumers learn about factory farming cruelties, the more they insist upon better treatment for animals. There is a long way to go before we end farm animal abuse, but today's announcement sets the country on a clear trajectory on factory farming issues." The article noted that Burger King will/has:

(1) Begun purchasing $2 \%$ of its eggs from producers that do not confine laying hens in battery cages and it will more than double the percentage of cage free hens it is using to $5 \%$ by the end of 2007 ,

(2) Implemented a purchasing preference for cage-free hens. Such a preference is intended to favor producers that convert away from battery-cage confinement systems,

(3) Started purchasing $10 \%$ of its pork from producers that do not confine breeding pigs in gestation crates. The volume of pork purchases coming from gestation crate free producers will double to $20 \%$ by the end of 2007 ,

(4) It has also implemented a purchasing preference for pork from products that do not confine breeding sows in gestation creates and

(5) It has implemented a preference for producers that use controlled atmosphere stunning of chickens used for meat.

\section{FMI-NCCR}

In 2001 the National Council of Chain Restaurants (NCCR) and the Food Marketing Institute (FMI) formed an alliance to address animal welfare. Both FMI and NCCR formed an animal welfare program to review producer guidelines and to create a process where third party auditing could be conducted to assure that food animals are raised, handled, transported and harvested under controlled, animal welfare guidelines (FMI, 2003).

The FMI-NCCR Animal Advisory Group ${ }^{1}$ had the following objectives when reviewing producer guidelines (1) To compare the guidelines to FMI-NCCR guidance, (2) Recommend changes for current practices that do not meet FMI-NCCR criteria and (3) To encourage research. In June 2002 FMI-NCCR released their first report on producer guidelines (http://www.fmi.org/animal welfare/). For the pork industry, FMI-NCCR endorsed the sow performance guidelines as printed in the Swine Care Handbook and the following statement was presented: "One of the most challenging issues the pork industry faces is confinement of gestating sows. Current pork industry guidelines include several enhancements regarding sow stalls but our experts have challenged the industry to go further. As a short term measure the FMI and NCCR support enhanced pork industry guidelines regarding individual housing systems, including: (1) The pregnant sow should be able to lie down on her side without her teats extending into the adjacent stall, (2) Her head should not have to rest on a raised feeder, (3) Her rear quarters should not come into contact with the back of the stall and (4) The pregnant sow should be able to stand up unimpeded. Subsequent to this review the Pork Checkoff's Animal Welfare Committee amended the industry performance guidelines to say a sow in gestation housing should be able to: (1) Lie down without the head having to rest on a raised feeder, (2) Lie down without the rear quarters 
having to be in contact with the back of the stall, and (3) Easily lie down in full lateral recumbancy and stand back up. To date the FMI-NCCR animal welfare advisory group has worked through all the commodity groups' welfare related material in the U.S.A. with varying outcomes and finalizations. Table 1 indicates the status chart of the FMI-NCCR process.

\section{Processing plants}

Not all the attention pertaining to farm animal welfare is focused on the farm; in fact all stages of the chain of production (farm to fork) are under scrutiny. Jones (2008) on behalf of the Animal Welfare Institute reviewed and summarized data obtained from more than 60 public records requests to federal and state agriculture departments, as well as other documents, covering a five-year period from 2002 through 2007. One section entitled "Non-compliance records" (NR's) details the role of the Food Safety Inspection Service (FSIS) inspection personnel present at slaughter establishments, for example what types of inspectors should be there and when and for what a NR was issued. In March 2004, a Freedom of Information Act (FOIA) request was submitted by Jones (2008) to FSIS for all NR's, citing the humane handling and slaughter inspection procedure code (04C02) issued to U.S.A. plants between October 1, 2002 and March 31, 2004. FSIS released a total of 424 records. Jones (2008) collated several tables in regards to NR's for issues pertaining to animal welfare at the plant that can be viewed in Table 2.

By August 2008 one of the largest upsets that has occurred in the industry to date was the incidence at the Chino CA (USA) processing plant, which was accused of supplying meat from at-risk cattle and treating weak animals cruelly. Westland Meat Co., Hallmark's distributor and a ground beef supplier for the National School Lunch Program, voluntarily halted operations at the time of the accusations (February 2008). USDA undersecretary for food safety Richard Raymond was quoted, "It was reported that the meatpacker clearly violated federal regulations and the Humane Methods of Slaughter Act." A video was released during this time period by
HSUS which showed slaughterhouse workers "forcing downer cows to their feet using sticks, ramming them with the blades of a forklift, jabbing them in the eyes, kicking them, applying painful electrical shocks and inserting a hose and forcing water up their noses in attempts to force sick or injured animals to walk to slaughter" (HSUS, 2008b). The CEO of HSUS Wayne Pacelle was quoted as saying "This torture is right out of the water-boarding manual. To see the extreme cruelties shown in the HSUS video challenges comprehension. This must serve as a five-alarm call to action for Congress and the U.S. Department of Agriculture. Our government simply must act quickly both to guarantee the most basic level of humane treatment for farm animals and to protect America's most vulnerable people, our children, needy families and the elderly from potentially dangerous food."

\section{PEW}

In April 2008 a project of The Pew Charitable Trusts and Johns Hopkins Bloomberg School of Public Health published a report titled, "Putting meat on the table: Industrial farm animal production in America" (PEW, 2008). The report was the result of a two year study that looked at areas of public health, environment, animal welfare and rural America. The report has separate chapters on each issue and then a PEW commission recommendation section. In summary the PEW commission noted for animal welfare that industrial farm animal production methods (IFAP) for raising food animals have generated concern and debate over just what constitutes a reasonable life for animals and what kind of quality of life we owe the animals in our care. PEW concluded that "it is an ethical dilemma that transcends objective scientific measures, and incorporates value-based concerns. Physical health as measured by absence of some diseases or predation, for example, may be enhanced through confinement since the animals may not be exposed to certain infectious agents or sources of injury that would be encountered if the animals were raised outside of confinement. It is clear, however, that good animal welfare can no longer be assumed based only on the absence of disease or productivity outcomes. Intensive confinement (e.g. gestation crates for swine, 
battery cages for laying hens) often so severely restricts movement and natural behaviors, such as the ability to walk or lie on natural materials, having enough floor space to move with some freedom, and rooting for pigs, that it increases the likelihood that the animals suffer severe distress. Good animal welfare can also help to protect the safety of our nation's food supply. Scientists have long recognized that food safety is linked to the health of the animals that produce the meat, dairy and egg products that we eat. In fact, scientists have found modern intensive confinement production systems can be stressful for food animals, and that stress can increase pathogen shedding in animals." Several recommendations for IFAP animal welfare prevailed from the PEW report and these were:

(1) The animal agriculture industry should implement federal performance-based standards to improve animal health and well-being,

(2) Implement better animal husbandry practices to improve public health and animal well-being,

(3) Phase out the most intensive and inhumane production practices within a decade to reduce IFAP risks to public health and improve animal well-being,

(4) Improve animal welfare practices and conditions that pose a threat to public health and animal well-being and

(5) Improve animal welfare research in support of cost-effective and reliable ways to raise food animals while providing humane animal care.

Being transparent, credible and accountability.

Numerous educational, assessment and certification programs have been created and marketed to ensure the transparency, creditability and accountability for the methodologies utilized in caring for farm animals. The following organizations have all created differing levels of accountability: American Humane Association; American Meat Institute, American Sheep Industry Association, Animal Welfare Institute, Humane Farm Animal Care, Milk and Dairy Beef, National Cattleman and Beef Association, National Chicken Council, National Pork Board, National Turkey Federation and the United Egg Producers (Table 3). The aim of any welfare approach should be to find solutions that are science based, transparent to the customer and workable, credible and affordable to those raising animals for food.

In addition to the National organizations efforts previously detailed on farm animal welfare, some agri-businesses are making company policy changes from within on how their animals are housed. Probably the largest announcement in 2007 came from Smithfield Foods, on January $25^{\text {th }}$. Smithfield Foods made a landmark decision regarding sow management in that they were beginning the process of phasing out the gestation stall. In a statement from Smithfield's web page they noted that "Beginning in 2007 and continuing over the next 10 years, our hog production subsidiary Murphy-Brown will move to using group pens for housing pregnant sows. The process will phase out individual gestation stalls on all company-owned sow farms in favor of group housing. We are also working with our contract growers regarding system conversion." The article further noted that Smithfield Foods based its decision on initial results from its own three-year study into sow housing to determine the impact such a switch would have on sows. Preliminary results showed that group housing arrangements worked as well as gestation stalls in providing sows with proper care during their pregnancies (Smithfield Foods, 2007).

Another interesting "alliance" of sorts came through the United Egg Producers (UEP) announcing an animal welfare relationship with the American Humane Association (AHA). PR Newswire (ALPHARETTA, Ga; March $24^{\text {th }}, 2008$ ) reported that UEP, a trade association representing most U.S.A. egg farmers and companies, has developed a new working relationship with the Denver-based American Humane Association, the only national organization dedicated to protecting both children and animals. Under terms of the agreement between the two organizations, UEP will recognize American Humane Certified ${ }^{\mathrm{TM}}$ animal welfare audits as also meeting UEP Certified standards if those egg producers also meet some additional criteria. The American Humane Certified program established guidelines for the production of eggs from hens in cage-free and free-range farm systems, while 
the UEP Certified program provides sciencebased guidelines for the production of eggs from hens either in modern cage production housing systems or cage-free farm systems. Under terms of the agreement, an egg farmer who passes the American Humane Certified audit, pays the fees and is a member in good standing with the UEP Certified Program and meets the UEP guidelines on $100 \%$ of their egg production, can then use the UEP Certified logo and market those eggs as UEP Certified in addition to marketing them as American Humane Certified and using the American Humane Certified logo. The advantage to an egg farmer is that they would not have to undergo and pay for a second audit of their farm, as UEP will accept the American Humane Certified animal welfare audit. "When UEP began developing science-based guidelines for the production of eggs in modern cage housing systems in the late 1990s, the American Humane Association participated in those discussions," said Gene Gregory, president of UEP. "We're pleased to renew a working relationship with them and we have always regarded them as one of the most credible animal-welfare organizations in the country." Marie Belew Wheatley, president and CEO of AHA, said, "We are enthusiastic about this agreement between our organizations that will facilitate certification of more egg producers who are in compliance with American Humane standards. Certification by both organizations assures consumers that they will be able to find humanely produced eggs in more locations."

Finally, there has been increasing pressure from companies that purchase animal protein for example McDonalds, Burger King, Kentucky Fried Chicken and Wal-mart that farm animal welfare assurances will be required in the future through timely and routinely completed third party audits. The aim of these audits will be to further enforce and "prove" back to the consumer (the general public) that animals that become food are cared for per program specifications. To date these are being completed in Federally inspected Pork, Beef and Chicken plants but there is continued discussion on the need for these audits to be taken further back, onto the farm (AMI, 2008; FACTA, 2008; PAACO, 2008, Validus, 2008).

\section{Legislation initiatives}

The regulation of food animal production has become part of mainstream life for European Union livestock and poultry producers. The transition was not without controversy and economic cost. The freedom that producers once had to produce animals as they saw fit gradually vanished by public command. In contrast, livestock and poultry producers in the U.S.A. have been relatively free of mandatory production standards until recently (Swanson, 2008) which will now be discussed.

\section{U.S.A. Federal laws}

The Humane Methods of Slaughter Act (1958) sets forth to "to establish the use of humane methods of slaughter of livestock as a policy of the United States, and for other purposes." The Act covers ante-mortem handling of animals, in addition to the slaughter process itself. It requires that animals be made insensible to pain by "a single blow or gunshot or an electrical, chemical or other means that is rapid and effective" prior to being shackled, hoisted or cut. In addition to these stunning methods, ritual slaughter in accordance with the requirements of a religious faith is deemed to be humane. The Act also provides a specific exemption for ritual slaughter. The humane slaughter law requires pre-slaughter stunning of cattle, calves, horses, mules, sheep, swine, and other livestock. However, the 1978 amendments to the Federal Meat Inspection Act reference of cattle, sheep, swine, goats, horses, mules, or other equine with no mention of other livestock. The nation's humane slaughter laws currently do not cover $98 \%$ of animals killed for food, as the USDA has not applied the federal livestock law to poultry. Another federal regulation called the 28 hour law originally passed in 1873 (49 U.S.C. 80502, last amended in 1994; 2005 to include road), notes that many types of carriers "may not confine animals in a vehicle or vessel for more than 28 consecutive hours without unloading the animals for feeding, water, and rest."

\section{U.S.A. State laws}

Animal rights and animal welfare groups are combining efforts. These efforts include the 
campaigning efforts previously discussed, in addition to purchasing shares and stocks in fast food chain and food retail companies and most currently are utilizing the law of the land to curtail and limit certain housing systems that are widely used in the U.S.A. In 2003 Amendment 10 in Florida banned the gestation stall, which will come into effect November 2008, which "prevents a person from confining a pig during pregnancy in an enclosure, or to tether a pig during pregnancy, on a farm in such a way that she is prevented from turning around freely." The ballot measure provided the following exemptions:

(1) During the pre-birthing period,

(2) When a pig is undergoing an examination, test, treatment or operation carried out for veterinary purposes, provided the period during which she is confined or tethered is not longer than reasonably necessary and

(3) When she has given birth and is housed with her piglets in a farrowing crate. Proposition 204 in Arizona (2006) will come into effect January $1^{\text {st }} 2013$. The act will amend the Arizona criminal code to make it a class 1 misdemeanor to tether or confine a pig during pregnancy or a calf raised for veal on a farm for all or the majority of a day in a manner that prevents the animal from lying down and fully extending its limbs or turning around freely. The law would not apply to pigs or calves while undergoing an examination, test, treatment or operation for veterinary purposes or for a pig during the seven day period before the pig's expected date of giving birth. Oregon (SB 694) followed suit in 2007. In Oregon the law notes that "this act prohibited confining pigs during pregnancy for more than 12 hours a day in a manner that prevents them from lying down, fully stretching their limbs or turning around freely." In May, 2008 Bill SB, 201 was signed by the Governor of Colorado that will phase out the gestation and veal stalls. This act will phase out veal stalls within four years and gestation stalls within 10 years. Colorado is now the first state in the country to ban the use of gestation crates and veal crates by action of a state legislature.

\section{On the docket}

In California a measure entitled Prevention of Farm Animal Cruelty Act (File No. 07-0041) seeks to prohibit veal and gestation stalls and battery cages. If successful, this act effective January 1, 2015 would prohibit with specified exceptions, the confinement on a farm of pigs, calves, and hens in a manner that does not allow them to turn around freely, lie down, stand up, and fully extend their limbs. Under the measure, any person who violates this law is guilty of a misdemeanor and may be punished by a fine of up to $\$ 1,000$ or imprisonment in county jail for up to six months. The act officially qualified for November's 2008 ballot. Another area that is receiving attention is a Federal Bill titled the Downed Animal and Food Safety Act (S. 394 \& H.R. 661) which aims to end the use of nonambulatory livestock identified as animals "too sick or injured to stand or walk on their own; in human food and require that these "downed" animals be immediately humanely euthanized at slaughter plants. "The aim of this piece of legislation is to amend the Federal Meat Inspection Act to strengthen the food safety inspection system by imposing stricter penalties for the slaughter of non-ambulatory livestock and for humane handling violations.

Another piece of legislation titled Farm Animal Stewardship Purchasing Act (HR 1726) supported by HSUS is currently in session. This act would require producers supplying meat, dairy products, or eggs to the military, federal prisons, school lunches, and other federal programs to comply with basic animal welfare requirements. The bill would not permit government suppliers to:

(1) Starve or force feed animals,

(2) Leave sick or injured animals to languish without treatment or humane euthanasia, and

(3) Confine animals so restrictively that they are unable to stand, lie down, move their heads freely, turn around, or extend their limbs.

It is predicted that (1) legislative initiatives will continue state by state, driven by animal humane and rights groups and (2) that such initiatives will be focused on more traditional agriculture states for example lowa, Illinois and Indiana. Although most of the legislative focus has been directed towards housing systems for the gestating sow, veal calf and the laying hen it should not be ruled out that other areas pertaining to animal welfare will be pursued over the next few decades. It is anticipated that efforts 
will be challenged into animal processing (castration, de-horning, tail docking and branding) on farm and livestock transportation, in particular length of time an animal can be moved and space requirements on the vehicle.

\section{CONCLUSION}

All individuals involved in the business of keeping animals for food have a huge responsibility in making sure that their animals are housed, raised, transported and processed humanely. The animal livestock industries will need to be on the forefront of the welfare issues that pertain to their industry and in addition will need to show increasing accountability back to their customers and consumers that farm animal welfare is of critical importance.

\section{REFERENCES}

AMERICAN HUMAN ASSOCIATION. AHA. American Humane Certified ${ }^{\circledR}$. 2008. Available at http://www.americanhumane.org/site/PageServer Accessed 10 june 2008.

AMERICAN MEAT INSTITUTE. AMI. 2008. Animal Handling and Audit Guidelines. Available at: http://www.meatami.com/. Accessed 10 june 2008.

ANIMAL WELFARE INSTITUTE. AWI. 2008. Animal Welfare Approved. Available at: http:// www.awionline.org/. Accessed 06 june 2008.

BARNETT, J.L.; HEMSWORTH, P.H.; CRONIN, G.M.; NEWMAN, E.; MCCALLUM, T.H. Effects of design of individual cage-stalls on the behavioural and physiological responses related to the welfare of pregnant pigs. Applied Animal Behaviour Science Amsterdam: North-Holland, v. 32, n. 1, p.23-33, 1991.

BRAMBELL, F. W. R. Report of the Technical Committee to Enquire into the Welfare of Animals kept under Intensive. Livestock Husbandry Systems Majesty's London.: Her Majesty's Stationery Office, 1965.

BROOM, D. M. Indicators of poor welfare. British Veterinary Journal. London, UK v.142, p. 524-526, 1986.

DUNCAN, I.J.H. Animal rights - animal welfare: a scientists assessment. Poultry Science, Savoy IL, v.60,n. 3, 489-499, 1981.

DUNCAN, I.J.H.; PETHERICK, J.C. The implications of cognitive processes for animal welfare. Journal of Animal, Science, Savoy, II, v,69, n. 12, 5017-5022, 1991.

DUNCAN, I.J.H.; DAWKINS, M.S. The problem of assessing "well-being" and "suffering" in farm animals. In: SMIDT, D (Ed.) Indicators relevant to farm animal welfare. Boston / Lancaster: Martinus Nijhoff, The Hague, 1983 p. 13-24.

FARM ANIMAL CARE TRAINING AND AUDITING. Campinas: FACTA. 2008. Available at: http://www.factallc.com/. Accessed 10 june 2008.

FOOD MARKETING INSTITUT- FMI. Arlington, VA : FMI Available at: http://www.fmi.org/animal_welfare/. Accessed 06 june 2008.

HUMANE FARM ANIMAL CARE. HFAC. Herndon, VA: HFAC, 2008. Certified Humane Certification Program. Available at: http://www.certifiedhumane.com/. Accessed 10 june 2008.

HUMANE SOCIETY OF THE UNITED STATES. HSUS. Washington, DC: HSUS, 2008a. Available at: http://www.hsus.org/ace/352. Accessed 06 june 2008.

HUMANE SOCIETY OF THE UNITED STATES. HSUS. Washington, DC: HSUS, 2008b. Available at: https://community.hsus.org/campaign/2008_downer_investigation2. Accessed 06 June 2008.

JONES, D. Crimes without consequences: the enforcement of humane slaughter laws in the United States. Washington DC : Animal Welfare Institute, 2008. Available at: http://www. awionline.org/farm/pdf/08SlaughterReport.pdf Accessed 10 june 2008.

MASON, J.; SINGER, P. Animal factories: what agribusiness is doing to the family farm, the environment and our health. Out of print. NewYork: Crown, 1980.

MENCH J.A.; JAMES H.; PAJOR E.A.; THOMPSON P.B. The welfare of animals in concentrated animal feeding operations. In: june 2008. 
Report to the Pew Commission on Industrial Farm Animal Production. Washington, DC. Pew Commission on Industrial Farm Animal Production, 2008

MILK AND DAIRY BEEF. The Pennsylvania State University 2008. Available at: http://www. dqacenter.org/. Accessed 10 june 2008.

MORMĖDE, P. Neuroendocrine responses to social stress. In: ZAYEN, R.; DANTZER, R, (Eds.) Social stress in domestic animals. Boston/ London: Kluwer Academic Publishers Dordrecht, 1990, p. 203-211.

NATIONAL CATTLEMAN AND BEEF ASSOCIATION - NCBA .Colorado: NCBA, 2008. Available at: http://www. beef.org/ Accessed 10 june 2008.

NATIONAL CHICKEN COUNCIL. NCC. Washington, DC: NCC, 2008. Available at: http://www. nationalchickencouncil.com/. Accessed 10 june 2008.

NATIONAL COUNCIL OF CAIN RESTAURANTS. NCCR. Minneapolis, MN:The Pillsbury Company, 2008. Available at: http://www.nccr. net/newsite/index.html. Accessed 06 June 2008.

NATIONAL PORK BOARD. NPB. Des Moines, IA: Pork Board, 2008. PQA Plus. Available at: www.pork.org Accessed 10 june 2008.

NATIONAL PORK BOARD. NPB. Des Moines, IA: Pork Board, 2008. Consumer eating trends. Meat consumption attitudes on pork. Available at: http://www.porkfoodservice.com/ documents/Meat $\% 20$ Consumption $\% 20 \& \% 20$ Attitudes $\% 20$

Towards\%20Pork.ppt\#791,19, Consumers.Accessed 10 june 2008.

NATIONAL TURKEY FEDERATION. NTF. Animal Care Best Management Practices for the production of Turkey. New York: NTF, 2008. p.7 Available at: http://www.eatturkey.com/. Accessed 10n June 2008.

PEOPLE FOR THE ETHICAL TREATMENT OF ANIMALS - PETA. Norfolk, VA : PETA, 2008a. Available at: http://www.peta.org/. Accessed 06 june 2008.

PEOPLE FOR THE ETHICAL TREATMENT
PETA, 2008b. Available at: http://www.peta2. com/woof/index.asp. Accessed 06 june 2008.

PEOPLE FOR THE ETHICAL TREATMENT OF ANIMALS. PETA. Meet your meat. Norfolk,VA : PETA, 2008c Av

PEW COMMISSION ON INDUSTRIAL FARM ANIMAL PRODUCTION. Putting meat on the table: industrial farm animal production in America. Washington, DC: PCIFAP 2008. Availableat:http://www.pewtrusts.org/uploadedFiles/wwwpewtrustsorg/Reports/Industrial_Agriculture/PCIFAP_FINAL.pdf. Accessed 06 June 2008.

PROFESSIONAL ANIMAL AUDITOR CERTIFICATION ORGANIZATION - PAACO. Redfield, IA: PAACO, 2008. Available at: http://www.animalauditor.org/paaco/. Accessed 06

SINGER, P. Animal Liberation: a new ethics for our treatment of animals. 2.ed. New York: Random House, 1990.

SMILHFIELD Foods Inc. Dublin, IE, jan, 2007.

SWANSON, J.C. Bioethics - Livestock and poultry: the ethics of food animal production: processing, and marketing. The ethical aspects of regulating production. Poultry Science, Savoy, IL , v. 87, 373-379, 2008.

UNITED EGG PRODUCERS. UEP. Animal husbandry guidelines for US egg laying flocks. Washington, DC: UEP, 2008.Available at: http:// www.unitedegg.org/. Accessed 10 june 2008.

VALIDUS SERVICES. Animal welfare. Des Moines, lowa: Validus, 2008. Available at: http:// www.validusservices.com/default.asp? keyPage=8. Accessed 10 June 2008.

WARNIER, A.; ZAYAN, R. Effects of confinement upon behavioural, hormonal response and production indie in fattening pigs. In: ZAYAN, $R$ (Ed.). Social space for domestic animals, Boston/London: Kluwer Academic Publishers Dordrecht, 1985, p.128-150. 
Table 1 - FMI-NCCR Animal Welfare Guideline Status Chart. March 2007.

\begin{tabular}{|c|c|c|}
\hline Producer organiration & FMI - NCCR Endorsement & Points of difference \\
\hline American Meat Institute & $\begin{array}{l}\text { Endorsed slaughter guidelines \& } \\
\text { training materials for cattle, swine, } \\
\text { sheep and goats (2002) }\end{array}$ & None \\
\hline $\begin{array}{l}\text { Milk and Dairy Beef } \\
\text { Quality Asurance } \\
\text { Centre (DQA); National } \\
\text { Milk Producers } \\
\text { Federation }\end{array}$ & $\begin{array}{l}\text { Endorsed DQA's Animal Care } \\
\text { Guidelines and training program } \\
\text { for milk and dairy beef ( } 2002)\end{array}$ & None \\
\hline $\begin{array}{l}\text { National Chicken } \\
\text { Council }\end{array}$ & $\begin{array}{l}\text { Endorse d slaughter guidelines for } \\
\text { broiler chicke ns (2003) } \\
\text { Endorsed arimal welfare } \\
\text { guide lines for production, } \\
\text { transportation and } \\
\text { e uthanasia(2004) }\end{array}$ & $\begin{array}{l}\text { None } \\
\text { None }\end{array}$ \\
\hline National Pork Board & $\begin{array}{l}\text { Endorsed animal welfare } \\
\text { guide lines of the swine industry } \\
\text { (2004) }\end{array}$ & $\begin{array}{l}\text { Policy state ment on } \\
\text { housing for pregnant } \\
\text { sows. }\end{array}$ \\
\hline $\begin{array}{l}\text { National Turkey } \\
\text { Federation }\end{array}$ & $\begin{array}{l}\text { FMI - NCCR Advisors are } \\
\text { reviewing production and } \\
\text { slaughter guide lines }\end{array}$ & $\begin{array}{l}\text { Guideline review not } \\
\text { completed }\end{array}$ \\
\hline United Egg Producers & $\begin{array}{l}\text { Endorsed production, handling, } \\
\text { transportation, processing and } \\
\text { e uthanasia guide lines for layers of } \\
\text { shell and braking eggs (2002) }\end{array}$ & None \\
\hline
\end{tabular}

Table 2 - Federal violations by type. October 1, 2002 to March 31, 2004(Jones, 2008).

\begin{tabular}{|c|c|c|}
\hline Type & Mmber & Feroent \\
\hline Failure to prouide uater in pen & 123 & 245 \\
\hline Pere or gounds in disepair & 80 & 160 \\
\hline Congoious animal on tleed rail & 77 & 15.4 \\
\hline heffEtiue sturining & 65 & 130 \\
\hline Imprper handling of digabiled animal & 51 & 102 \\
\hline Slippery эurtases f fallirg & 27 & 5.4 \\
\hline hadequate space in pen for lying & 25 & 5.0 \\
\hline Eursaine forto teed to drive animals & 24 & 4.8 \\
\hline Dther & 20 & 4.0 \\
\hline Failure to prouide toud in per & 9 & 1.7 \\
\hline Tota & 5011 & . \\
\hline
\end{tabular}


Table 3 - Major U.S. Farm animal welfare standards (Mench et al., 2008).

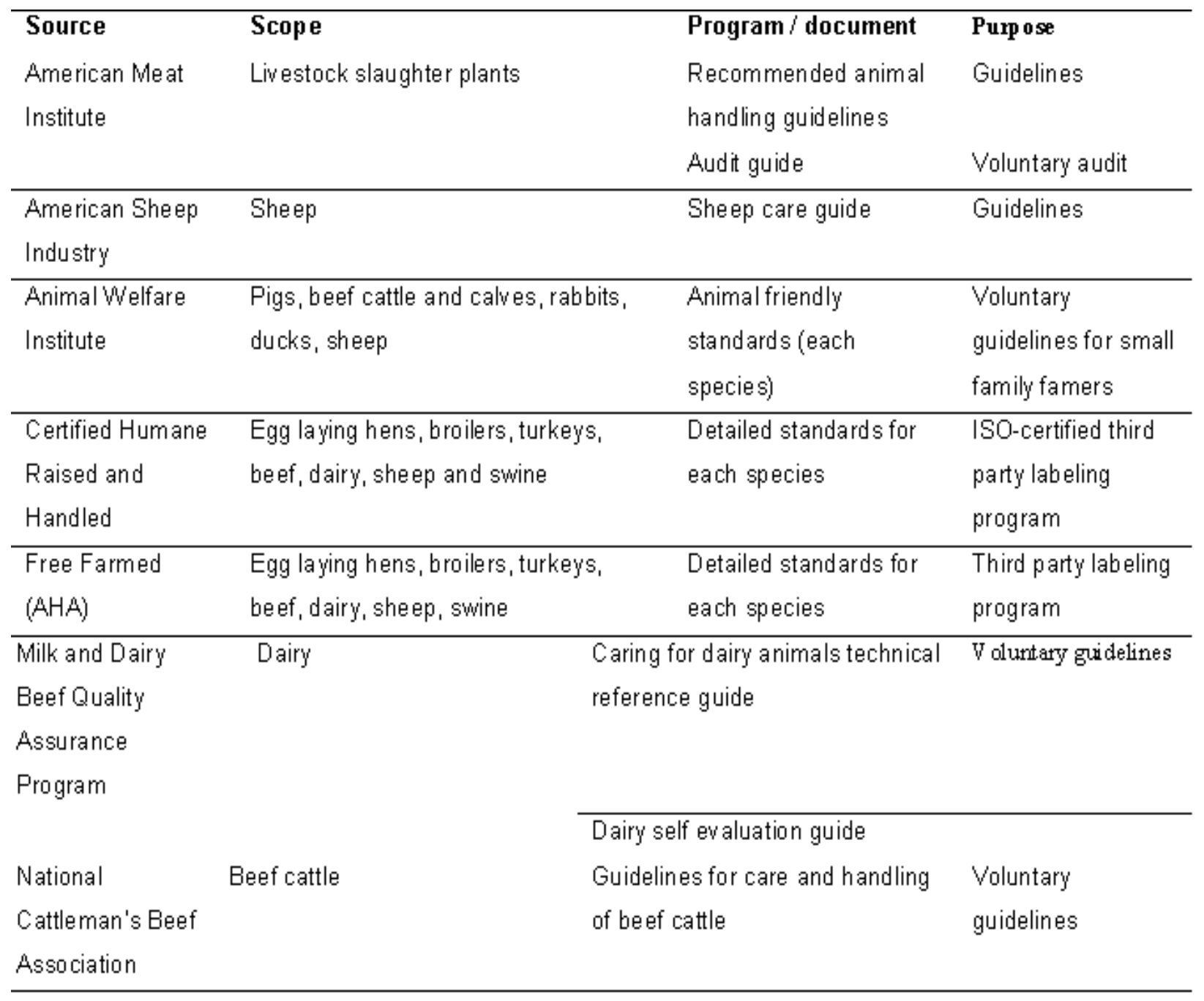


Table 3 - Continued; Major U.S. Farm animal welfare standards (Mench et al., 2008).

\begin{tabular}{|c|c|c|c|}
\hline SOUTi' & Sago & Frogram idoustm gnt & 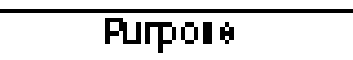 \\
\hline \multirow[t]{2}{*}{ 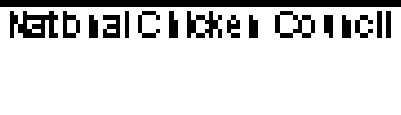 } & \multirow[t]{2}{*}{ 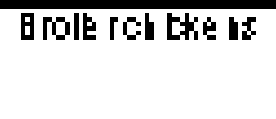 } & Álmaluétige gube lhés & 'Wold i teru' gu be lhè \\
\hline & & Ándtohedilts & 'volul t tery' ald \\
\hline 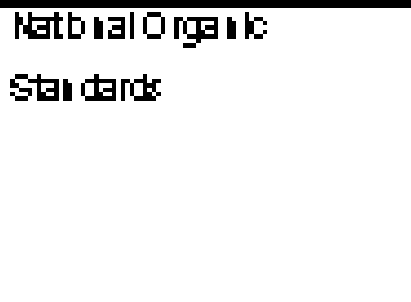 & $\begin{array}{l}\text { All vertidi and } \\
\text { pon ty }\end{array}$ & 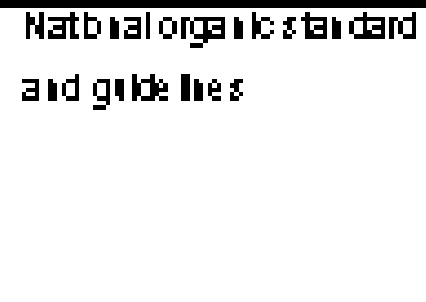 & 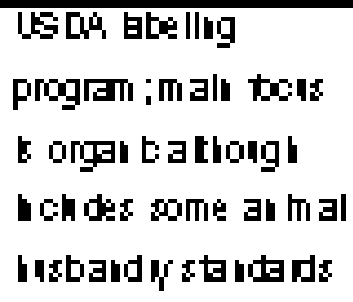 \\
\hline l'tetb hal Pok Bogrd & $P$ & 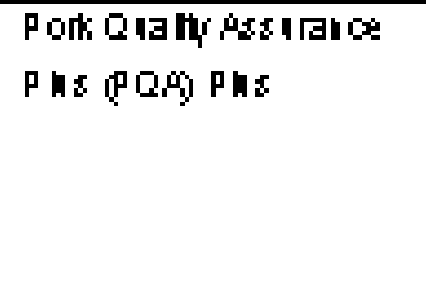 & 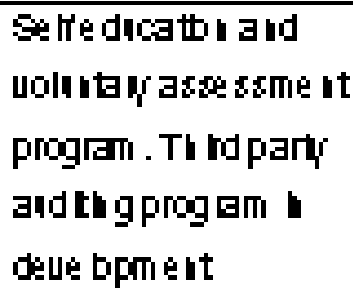 \\
\hline \multirow[t]{2}{*}{ Uh ted Gg P Pod los rs } & \multirow[t]{2}{*}{ Gaged Giét: } & 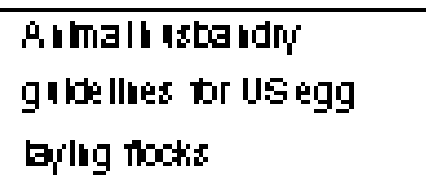 & $\begin{array}{l}\text { Gilde lhes tr coged } \\
\text { helt }\end{array}$ \\
\hline & & 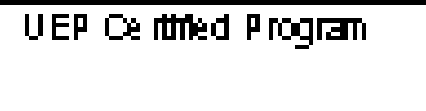 & 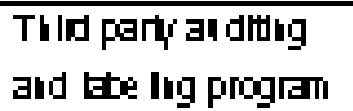 \\
\hline
\end{tabular}

